\title{
Evaluation of groundwater potential of bedrock aquifers in Geological Sheet 223 llorin, Nigeria, using geo-electric sounding
}

\author{
W. O. Raji ${ }^{1,2} \cdot$ K. A. Abdulkadir ${ }^{1}$
}

Received: 14 April 2020 / Accepted: 3 September 2020 / Published online: 17 September 2020

(c) The Author(s) 2020

\begin{abstract}
Electrical resistivity data acquired in one hundred and ten (110) locations using vertical electrical sounding method of Schlumberger array have been used to study the hydrogeological properties and groundwater storage potential of bedrock aquifers in an area covered by Geological Sheet 223 Ilorin, Nigeria. The aim of the study was to identify productive aquifer zones for citing boreholes for community water supply. The data acquired were processed and interpreted using auxiliary curve matching and computer automation method to delineate the different geo-electric layers, their resistivities, thicknesses, and depths. Geo-electrical layers were interpreted to their equivalent geological layers using borehole lithological logs from the study area. Then, the hydraulic conductivity, transmissivity, fracture contrast, reflection coefficient were estimated and plotted in the form of 2D maps to describe the spatial variations of these parameters in the area. The results of the study revealed the presence of three to five geo-electric layers. The geo-electric layers, from top to the bottom, corresponds to the topsoil layer, lateritic layer, weathered rock layer, fractured rock layer, and the fresh basement rock. Lateritic and/or fractured rock layers were not delineated in some places. The weathered and fractured rock layers, where present, correspond to the aquifer units. The thickness of the fracture aquifer ranges from 0.6 to $33.6 \mathrm{~m}$ while the thickness of the weathered aquifer ranges from 1.4 to $49.3 \mathrm{~m}$. The transmissivity, $T$, and hydraulic conductivity, $K$, range from 3 to $1200 \mathrm{~m}^{2} /$ day and 1 to $48 \mathrm{~m} /$ day, respectively. The reflection coefficient and fracture contrast map showed the presence of water-bearing fractures and shared some similarities with $T$ and $K$ maps. A mathematical model for predicting groundwater potential, $\mathrm{GW}_{\mathrm{P}}$, of weathered aquifer in the basement complex terrain was proposed in this study. The consistencies between the overall groundwater potential map and aquifers parameters distributions maps suggest the appropriateness of the proposed mathematical model for predicting groundwater potential of weathered rock in the basement complex area of Nigeria. The western, northwestern, and central parts of the study area, having $\mathrm{GW}_{\mathrm{P}}$ greater than $0.6(60 \%)$, were recommended for groundwater development through boreholes drilled to a depth ranging between 75 and $100 \mathrm{~m}$.
\end{abstract}

Keywords Crystalline aquifers · Groundwater potentials · Vertical electrical sounding · Fracture coefficient · Hydraulic conductivity $\cdot$ Transmissivity

\section{Introduction}

Climate change is anticipated to affect groundwater availability throughout Africa than it was previously forecast. In addition to shortage in rainfall and excessive loss in surface water due to temperature rise and prolonged evaporation,

W. O. Raji

Wasiu.raji@gmail.com

1 Department of Geophysics, University of Ilorin, PMB 1515, Ilorin, Nigeria

2 Department of Geology and Mineral Sciences, University of Ilorin, PMB 1515, Ilorin, Nigeria surface and rain water are severely polluted and unfit for human consumption without prior treatment. Currently, there is heavy dependence on groundwater to meet daily global demand for fresh water. Groundwater accounts for more than $95 \%$ of worldwide storage for fresh water (Shiklomanov 1998; Healy et al. 2007). However, groundwater is not evenly distributed in the subsurface. Groundwater distribution is affected by a number of factors including porosity and permeability of the subsurface rocks, amount of rainfall and surface water available for recharge, topography, size of the aquifer, nature of the overburden material among others (Bhattacharya and Patra 1968; Kosinski and Kelly 1981; Kalinski et al. 1993; Olayinka 1996). An aquifer is a body 
of earth material that contains sufficient permeable material to yield significant quantity of water to wells. On a regional annual scale, changes in sedimentary aquifer storage are negligible because water can easily flow from areas of surplus to areas of deficit. On a local scale, in hard rock terrain, changes in aquifer storage, due to groundwater withdrawal can be substantial and significant because the aquifers have limited extent, are not interconnected and poorly recharge (Healy et al. 2007; Raji et al. 2019; Raji and Abdulkadir $2020 \mathrm{a}, \mathrm{b})$. This is why groundwater scarcity is common in the basement rock terrain.

Due to global warming, smaller duration high-intensity rainfall showers have now replaced the longer duration lowintensity rainfall events. Consequently, the runoff component of rainfall has increased, thereby reducing aquifer recharge and groundwater availability (Vashisht and Aggarwal 2016). Sedimentary rock aquifers are easily recharged, and they store more water than the crystalline rock aquifers (otherwise known as hard rock aquifers, or bedrock aquifers) due to the abundant interconnected pore spaces in the former and lack of pore spaces in the later. Crystalline rocks are generally impervious to fluid except when it's decomposed by weathering, or fractured, jointed, and faulted by tectonic activities. Unfortunately, these impervious crystalline rocks cover about $50 \%$ of the land mass in Africa (MacDonald et al. 2012; UNEP Africa Water Atlas 2020). Groundwater development in hard rock terrain requires carefully designed pre-drill geophysical survey targeted at determining the hydro-geophysical properties and the approximate thicknesses and depths of the weathered and fractured rock layers in the subsurface. The ultimate target of such survey is to locate weathered horizons and/or bedrock with network of interconnected fractures that can store sufficient quantity of water and transmit same to well or boreholes. Weathered and fractured rocks are not evenly distributed in the subsurface. Therefore, the knowledge of the spatial distribution of hydraulic properties of rocks is essential for the prediction of groundwater availability, recharge, and yield in bedrock aquifers (Scanlon and Cook 2002; Ezeh 2011; Raji 2014).

Aside groundwater development for community supply, quantitative overview of hydraulic properties of bedrock aquifers is essential for ensuring all year round water supply for irrigation purposes. However, the evaluation of spatially quantitative dynamic properties of bedrock aquifers requires a deep understanding of the intrinsic rock properties that are not directly measurable by geophysical surveys. Hydraulic properties like yield, recharge, and specific capacity cannot be directly measured through any geophysical method, but can be indirectly inverted from the estimates of closely related parameters such as transmissivity, hydraulic conductivity, fracture coefficient, and fracture contrast (Niwas and Singhal 1981; MacDonald et al. 2001, 2012; Raji and Abdulkadir 2020b). Also, direct measurements of groundwater volume in bedrock aquifer is a difficult endeavor. But, quantitative estimates of aquifer thickness, porosity, storativity, fracture contrast, and fracture coefficient, among others, may be used to predict the volume of groundwater storable in an aquifer. Therefore, the evaluation of groundwater potentials and availability in aquifers should be based on sub-regional evaluation of aquifer properties rather than the local, on the spot, assessment as commonly done for borehole survey.

Electrical resistivity survey (ERS) is the most commonly use geophysical method for groundwater study in different geological terrains. ERS is a non-invasive depth probing techniques that is most suited for shallow subsurface study in built-up and undeveloped environments. ERS is environmentally friendly, operationally simple, cost effective, time inexpensive, and easy to deploy regardless of the geological terrain. 2D/3D electrical resistivity survey has evolved with technology, and is currently being used for groundwater survey in geologically complex areas. The cost of acquiring the equipment and interpretation packages is restricting the widespread use of 2D/3D methods. So 1D ERS is still reliable for groundwater exploration, and its chance of success can be enhanced by expert's knowledge and the availability of borehole lithologic logs in the study area. ERS method relied on the direct influence of moisture in rocks on the electrical conductivity of such rocks (Zohdy et al. 1974). Among the classical electrode arrays used for resistivity measurement, vertical electrical sounding (VES) of Schlumberger array is the most popular. A study by Raji et al. (2020) compared six classical electrode arrays for resistivity measurement in a field experiment in a basement complex terrain of Nigeria and showed that Schlumberger array is the most dependable method of probing earth resistivity with depth. Parameters inverted from VES measurements have been used for groundwater exploration and development, predicting aquifer seasonal behavior, aquifer vulnerability studies, and groundwater pollution from oil spillage and dump-site leachate in the different parts of the world (e.g., Kalinski et al. 1993; Olorunfemi and Fasuyi 1993; Edet et al. 1994; Sharma and Baranwal 2005; Viase et al. 2005; Casas et al. 2005; 2007; Abubakar and Danbatta 2012; MacDonald et al. 2012; Raji 2014; Abubakar et al. 2014; Raji and Adeoye 2017; Aluko et al. 2017; Raji et al. 2018; Raji and Abdulkadir 2020a). Therefore, VES method using Schlumberger electrodes array will be applied to interrogate subsurface geology for groundwater potential in this study.

The rate of abortive boreholes and the scarcity of portable water in the study area is the motivation for this study. 15-20\% borehole failure rate has been reported in the central part of the study area (Geo-Drill 2019, verbal communication). The aim of the study is to interrogate the subsurface geology for groundwater availability and identify the productive aquifer zones for groundwater development in the 
study area. The objectives of the study are to: characterize the subsurface geo-electric layers, determine depth to aquifers, and describe the dynamic hydraulic properties of the aquifers (e.g., transmissivity and hydraulic conductivity) in the study area. The expected outcome of this study include spatially quantitative maps of combined aquifer thickness, transmissivity (indicative yield), hydraulic conductivity (indicative recharge), fracture density map, and the overall groundwater potential map of the area. Data acquired for the study and the results obtained from the study, when published, will improve experts' understanding of the hydrogeology of the hard rock terrain.

\section{The study area and its geological setting}

The study area lies between latitudes $08^{\circ} 24.50^{\prime} \mathrm{N}$ and $08^{\circ}$ $27.99^{\prime} \mathrm{N}$ of the equator and longitudes $04^{\circ} 27.50^{\prime} \mathrm{E}$ and $04^{\circ}$ $41.00^{\prime} \mathrm{E}$ of the Greenwich Meridian (Fig. 1a, b). The area covers about 161 square kilometers in Ilorin South Local
Government of Kwara State and falls within Geological Sheet Ilorin 223 of the Nigerian Geological Survey Agency. The study area is part of the Savana region of Nigeria, has two main seasons-rain season and dry season. The mean annual rainfall and temperature range from 75 to $112 \mathrm{~mm}$ and 27 and $35{ }^{\circ} \mathrm{C}$. Drainage is provide by River Asa, River Oyun, their tributaries and distributaries. The mean daily sun shine is about 8 hours. Geologically, the study area falls within the Precambrian basement terrain of the southwestern Nigeria considered to be Precambrian to lower Paleozoic in age (Oyawoye 1964; Rahaman 1976; Annor et al. 1987). The rock comprised mostly gneiss, granite, schist, and undifferentiated meta-sediment. In the study area, the rocks outcrop in some places and are covered by weathered rock and topsoil in many places. The rocks are well exposed along river channels.

The oldest rocks in the study area comprise gneiss complex whose principal member are Biotite-HornblendeGneiss with intercalated Amphibolites (Annor et al. 1987). The younger suites are granites with medium to coarse

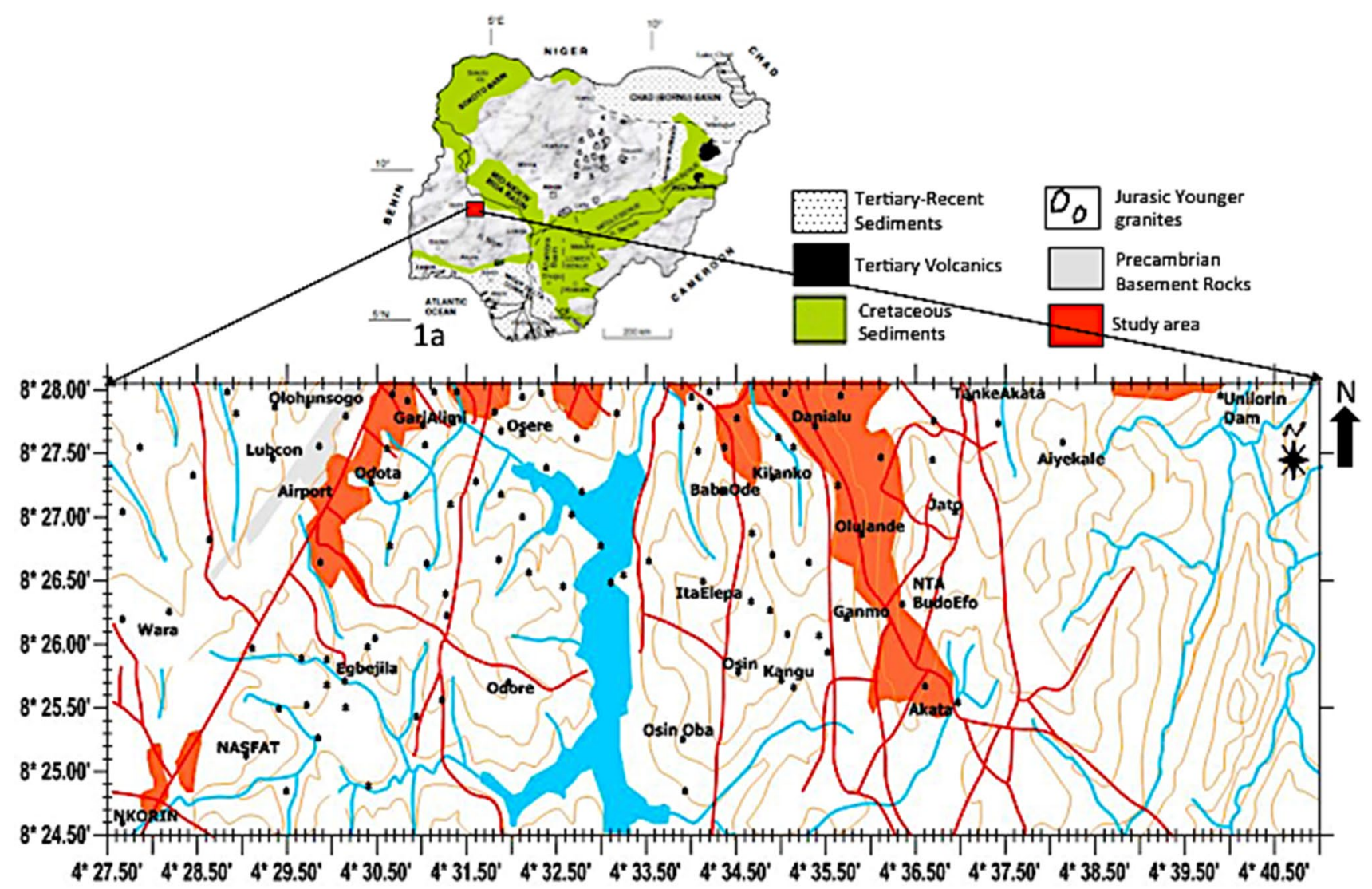

$1 \mathrm{~b}$

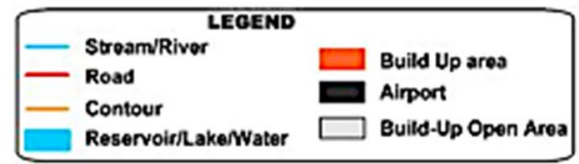

Scale $1 \mathrm{~cm}=1 \mathrm{~km}$

Fig. 1 a Geologic map of the Nigeria showing the location of the study area. b Map showing the location of VES survey points in the study area

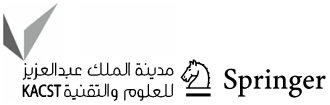


grains light colored rocks with variation in biotite content. In some places, the Biotite minerals are thread-like, arranged in roughly parallel pattern. In other places the Biotite minerals are disoriented in the ground mass. The feldspar mineral occurs as fine to medium grains. Other rock types include schist and quartzite. Minor bodies of pegmatites and quartz intruded the rock at different places during the Pan African orogeny (Oluyide et al. 1998). The quartzite, the metamorphic equivalence of quartz-rich sandstone, filled the preexisting fractures in the area. The rocks have been weathered at shallow depth in some places due to in situ physico-chemical activities. Structural features mapped in the area included fault, fracture, pinch and swell structure, strikes, and dips. The rocks are dipping to the west and east with angles ranging from $28^{\circ}$ to $45^{\circ}$.

Groundwater occurrence in the Precambrian basement terrain is hosted within zones of weathering and fracture which are not evenly distributed. The two main aquifer types in the study area are weathered rock and fractured rocks aquifers. The aquifers are overlain by different soil material of variable thickness. The soil materials include laterites, clay, sand, and silt-sized particles deposited by runoff and surface water. Aquifers in the basement complex of southwestern Nigeria are typically found at varied, but shallow depths, have limited extent, low porosity, and permeability. The aquifers depend on secondary porosity derived from weathering and fracturing, faulting, jointing, and cracking of rock units for transmitting fluid from one place to another (Davis and DeWiest 1966; Dan-Hassan 2001; Olasehinde and Raji 2007; MacDonald et al. 2012; Abubakar and Auwal 2012; Abubakar et al. 2014).

\section{Materials and methods}

One hundred and ten (110) points were survey in the different parts of the study area using Vertical Electrical Sounding Technique of Electrical Resistivity with Schlumberger electrodes array. Data acquisition equipment comprised ABEM 3000 Earth Resistivity Meter, two current and two potential electrodes, four reels of electrical cables, hammers, measuring tapes, battery, and portable geographic positioning system, GPS. The spacing between one survey point and the other ranges between 100 and $350 \mathrm{~m}$ depending on the available space for spreading electrodes and cables for the survey. The obstruction caused by the presence of building, roads, and other engineering infrastructure prevented regular spacing of VES stations. Current electrode spacing, AB, ranges from 1 to $200 \mathrm{~m}$. The GPS coordinates and elevation of every survey point were measured and recorded against the survey number for ease of geo-referencing. Locations of the VES stations are shown in the base map (Fig. 1b).
Resistance measured and resistivity computed were recorded against the respective current and potential electrode separation, and resistivity curve were plotted on the field for quality assurance purposes. In situation where a curve exhibits anomaly peaks in difference to the previous stations, the experiment is repeated to clear any doubt and reduce uncertainties. VES data were subjected to manual and automated processing to invert different geo-electric parameters. The raw data were pre-processed, where necessary to remove spikes and instrumental errors (e.g., contribution from low voltage, poor electrode contact, etc.) using a curve smoothing algorithm (Raji and Adeoye 2017) and the pre-processed/raw data were re-plotted on double logarithm papers. The curves on double logarithm papers were transferred to tracing papers and carefully interpreted using auxillary curve matching techniques (Orellana and Mooney 1966; Koefoed 1979; Telford et al. 1990) to deduce the approximate number of layers, the resistivity, and thickness of each geo-electric layer.

The field data and the number of layers obtained from the manually interpretation were input to WinResist-a computer iterative curve-matching software for final interpretation. The number of geo-electric layers obtained from auxiliary curve matching is used as the starting model in WinResist, rather than guessing the starting model. For an example, if four geo-electric layers were obtained from the manual interpretation, a minimum of three and maximum of five geo-electric layers are set as the model in WinResist. After a preset number of iterations, the software matches the curve from field data to a computer defined curve and output the estimated number of layers, resistivities, thickness and depth of each geo-electric layers, and the inversion uncertainties (RMS error). Some results from the curve-matching procedure are shown in Fig. 2a. The inversion error defines the misfit or mismatch between the field data curve and the computer defined curves. Where the misfit is higher than $10 \%$, the preset values, for examples, the number of layers, or number of iterations is reset, and the interpretation process is repeated until the RMS error falls within a reasonable limit (less than 10\%). To describe the hydraulic properties of the aquifers and the groundwater potential of the area, some parameters including hydraulic conductivity, transmissivity, fracture coefficient, and the groundwater potential were estimated at each of the 110 VES points. Hydraulic conductivity $(K)$ and transmissivity $\left(T_{r}\right)$ of the aquifer were estimated following the method of Heigold et al. (1979) and Niwas and Singhal (1981), as shown in Eqs. 1 and 2, respectively. Detailed explanations can be found in some recent literature (e.g., Obiora et al. 2016; Raji and Abdulkadir 2020b).

$K=386.40 R_{r w}^{-93283}$ 

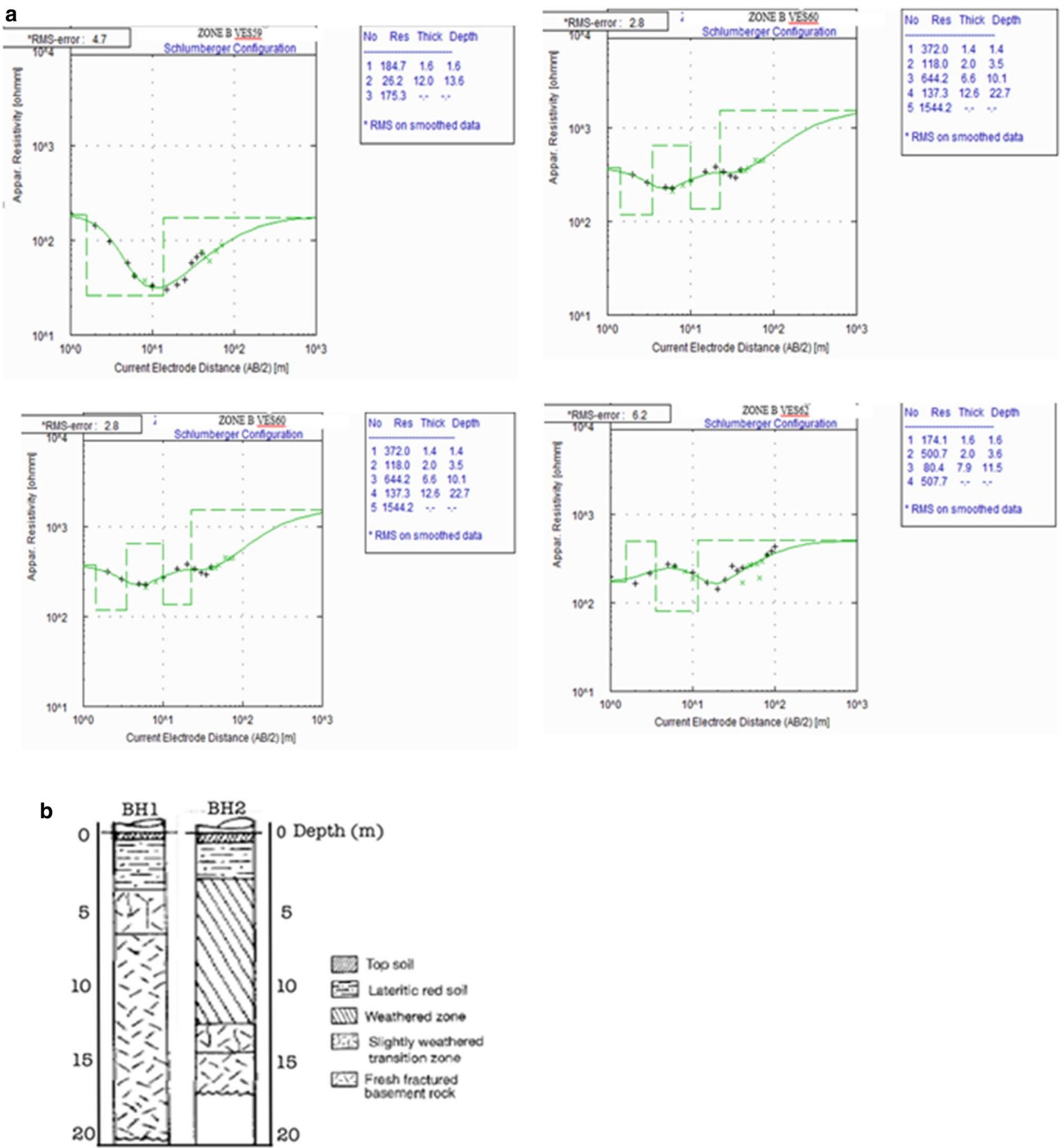

Fig. 2 a Some VES curves and their interpretations. b Lithologic logs from two boreholes in the study area

$T_{r}=K \sigma T=\frac{K S}{\sigma}=K h$

where $R_{r w}$ is the resistivity of the aquifer, $T, \sigma, S$, and $h$ are transverse resistance, conductivity of the aquifer layer, longitudinal conductance, and the thickness of the layer, respectively. Then, the reflection coefficient and fracture contrast of the weathered aquifers were computed following Eqs. 3 and 4 , respectively.

$R_{C}=\rho_{n}-\rho_{n-1} / \rho_{n}-\rho_{n+1}$ 
$F_{C}=\rho_{n} / \rho_{n-1}$

where $\rho_{n}$ is the apparent resistivity of a geo-electric layer and $\rho_{n-1}$ is the apparent resistivity of the geo-electric layer overlying nth layer. Finally, the groundwater potential of the area was estimated using a combination of different aquifer parameters which include combined aquifer thickness, fracture density, hydraulic conductivity and transmissivity, porosity, and overburden thickness. An empirical equation linking the overall groundwater potential $\left(\mathrm{GW}_{\mathrm{P}}\right)$ of the weathered rock aquifer to the different aquifer parameters is defined in Eq. 5.

$\mathrm{GW}_{\mathrm{P}}=h_{\mathrm{w}} T^{\theta} /\left(R_{\mathrm{c}} / F_{\mathrm{c}}\right)^{\theta}$

where $h_{\mathrm{w}}$ is the thickness of the weathered aquifer; $T$ is transmissivity; $\theta$ is the porosity; $R_{\mathrm{c}}$ is the reflection coefficient; and $F_{\mathrm{c}}$ is the fracture contrast. An effective porosity of $7.5 \%$ was used for this study. The value was adopted from range of values of $1-10 \%$ available in the literature on series of local, national, and regional studies on different types of crystalline aquifers across Africa and other parts of the world (Lott 1998; Petford 2003; Samaila and Singh 2010; MacDonald et al. 2012). The equation is applied at every VES survey point to compute the spatial distribution of groundwater potential for the study area. $\mathrm{GW}_{\mathrm{P}}$ at every point was normalized to a scale of 0-1 by dividing the value estimated at each VES point by the maximum values in the survey area. Areas with values greater than 0.6 was considered to have high groundwater potential $\left(\mathrm{GW}_{\mathrm{P}}>0.6\right)$.

\section{Results and discussion}

VES results show that the study area is underlain by three to five distinct geo-electric layers (Fig. 2a). Interpretation of the geo-electric layers to their corresponding geologic unit was guided by lithologic logs obtained from boreholes in the area (Fig. 2b) and previous studies in the area (Olasehinde and Raji 2007). The interpretation showed that the five geo-electric layers correspond to the topsoil layer, lateritic layer, weathered rock layer, fractured rock layer, and fresh basement rock, respectively. The three geo-electric unit that are consistently present in all the survey points are the topsoil layer, weathered rock layer, and the fresh basement rock. Lateritic layer and/or fractured rock layer are present in some places and absent in others. The various VES curves are best described by QQH, QHK, QHA curve types representing over $70 \%$ of the survey points. Two aquifer zones were delineated: the first aquifer zone corresponds to weathered rock layer, while the second aquifer zone corresponds to fracture rock layer. The thicknesses, resistivity, and other results were plotted, evaluated and used to compute some secondary parameters required for assessing the hydraulic properties of the aquifers and the groundwater potential of the study area.

Figure $3 \mathrm{a}, \mathrm{b}$ shows the thickness and resistivity of the weathered aquifer, respectively. The thickness of weathered aquifer ranges from 1.4 to $49.2 \mathrm{~m}$, while the resistivity ranges from 10.1 to $421 \Omega \mathrm{m}$. The thickest weathered aquifer zones are located in the extreme western part of the study area around VES stations 103, 109, and 108; in the northwestern part around VES stations 90, 97, 105, 101, and 100; and in the center of the study area around VES stations 69, 43,56 , and 57. Variation in the thickness of weathered zone suggests differences in the resistance of the rocks to weathering. It is note worthy that the thickest aquifers in the west, northwest and southwest correspond to very low resistivity values-ranging between 20 and $80 \Omega$ m (Fig. 3b). These values of resistivity suggest the presence of water in the weathered rock and the possibility of water-bearing fractures around the zone (Zohdy et al. 1974; Olayinka 1996; Asry et al. 2012).

Figure 4 shows that the thickness of overburden layer (unsaturated zone) in the study area ranges from 0.4 to $16.2 \mathrm{~m}$. Overburden thickness is estimated as the sum of the thicknesses of the topsoil and the lateritic layer in the respective VES stations. The thicker the unsaturated zone, the higher its capability to retain water from runoff during rainfall and transmit water to the aquifer zone. The unsaturated zone is moderately porous as it contains loose sand particle derived from weathered rocks and other material deposited by wind and runoff water. The zone is particularly useful for agricultural purpose. Figure 5 presents the spatial distribution of total aquifer thickness. The total aquifer thickness was estimated as the summation of the weathered aquifer and fractured rock aquifers thicknesses. The estimated value ranges from 4.5 to $82.8 \mathrm{~m}$. Areas having thick aquifer are potential places for groundwater storage. From the surface, depth to the aquifer bottom was estimated as the sum of the overburden thickness and the total aquifer thickness. Considering an additional $15 \mathrm{~m}$ column for groundwater storage or accommodation below the aquifer bottom (in the wells/drill hole), the borehole depth in the area was estimated to range from 75 and $100 \mathrm{~m}$.

The aquifer transmissivity $(T)$ plot presented in Fig. 6 shows that the estimated transmissivity ranges from 3 to $1200 \mathrm{~m}^{2} /$ day. Highest values were recorded in the northcentral, northwestern and southwestern parts of the study area. Aquifer transmissivity is an indirect indicator of yield (MacDonald et al. 2012), and it describes the lateral movement of groundwater in the aquifer. This why some authors including Acheampong and Hess (1998) and Graham et al. (2009) have found borehole yields to be directly related to transmissivity. Figure 7 shows the spatial distribution of the estimated hydraulic conductivity of the aquifers $(K)$ in the 


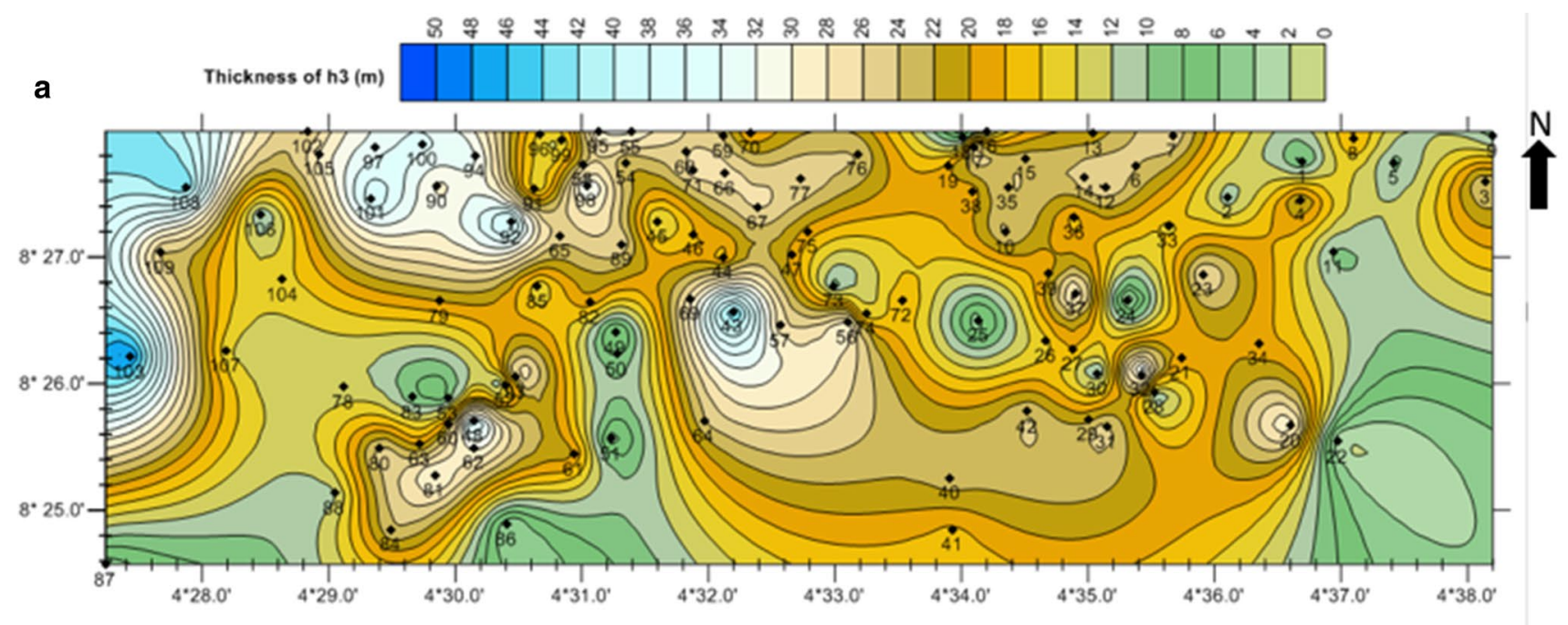

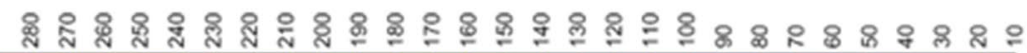
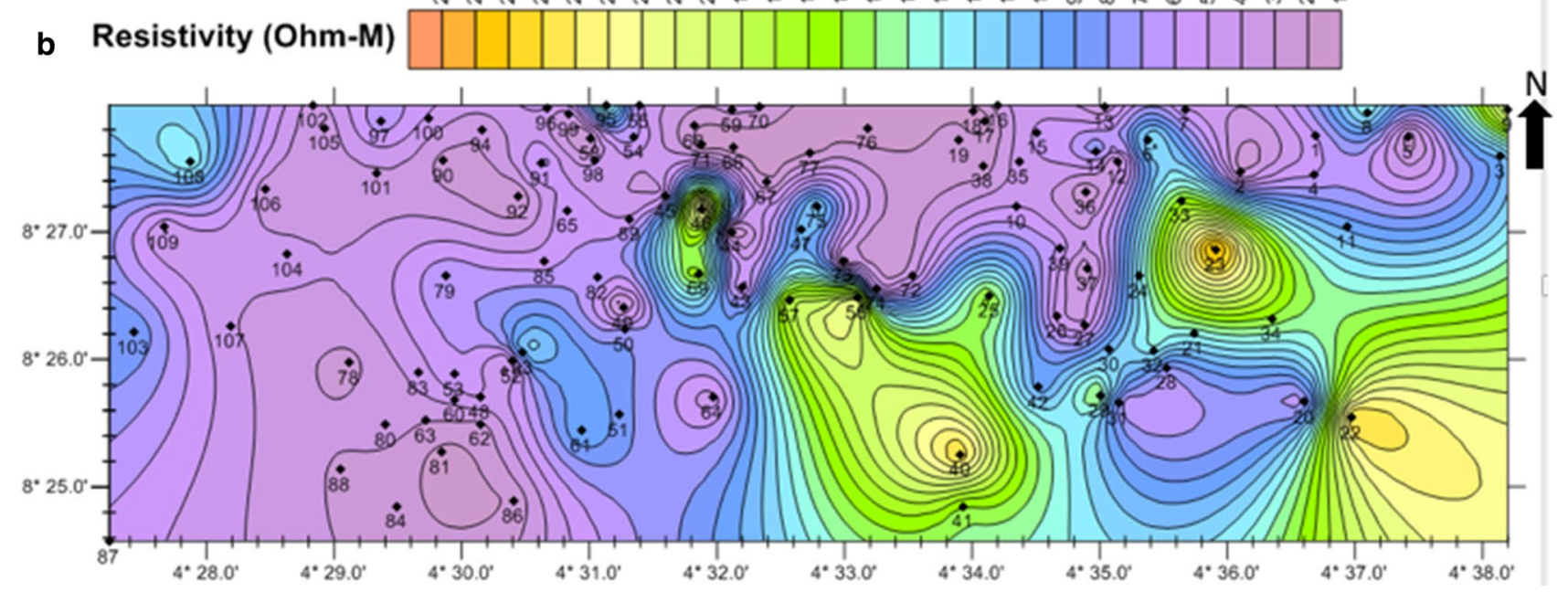

Fig. 3 a Estimated thickness of weathered aquifer. $\mathbf{b}$ Resistivities of the weathered aquifer

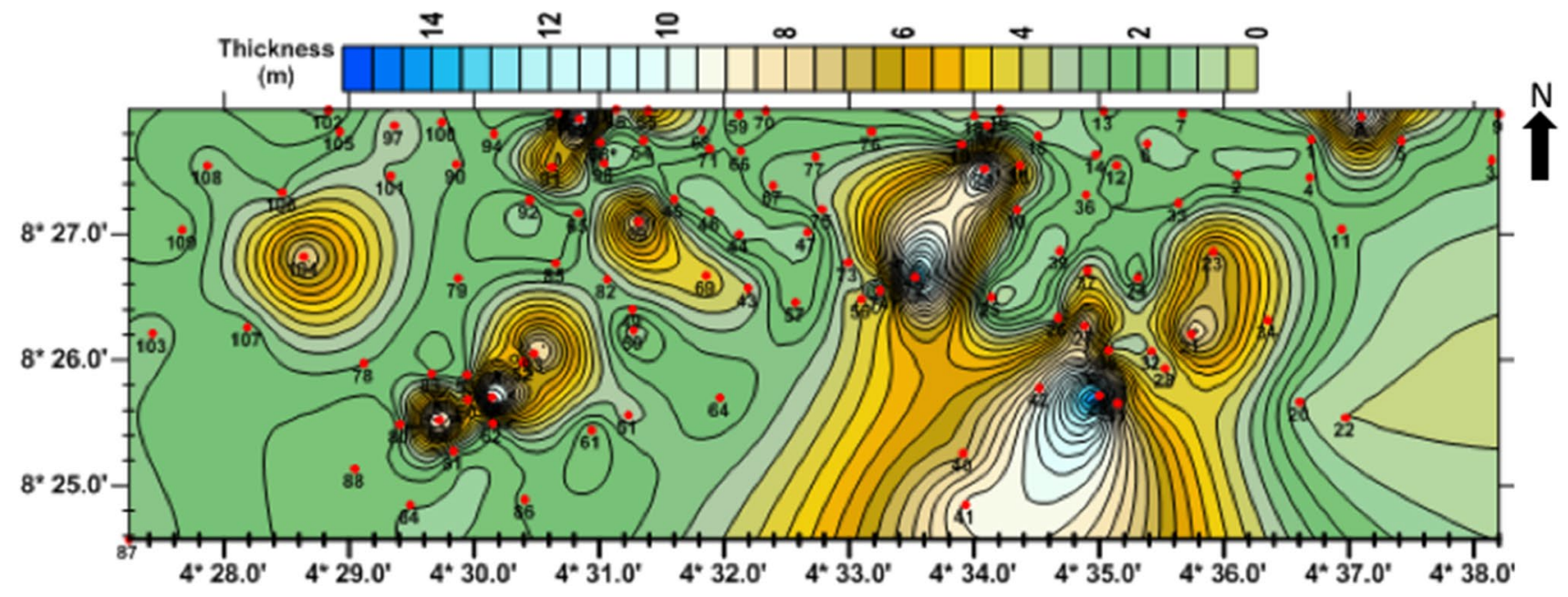

Fig. 4 Spatial distribution of unsaturated zone thickness in the study area 


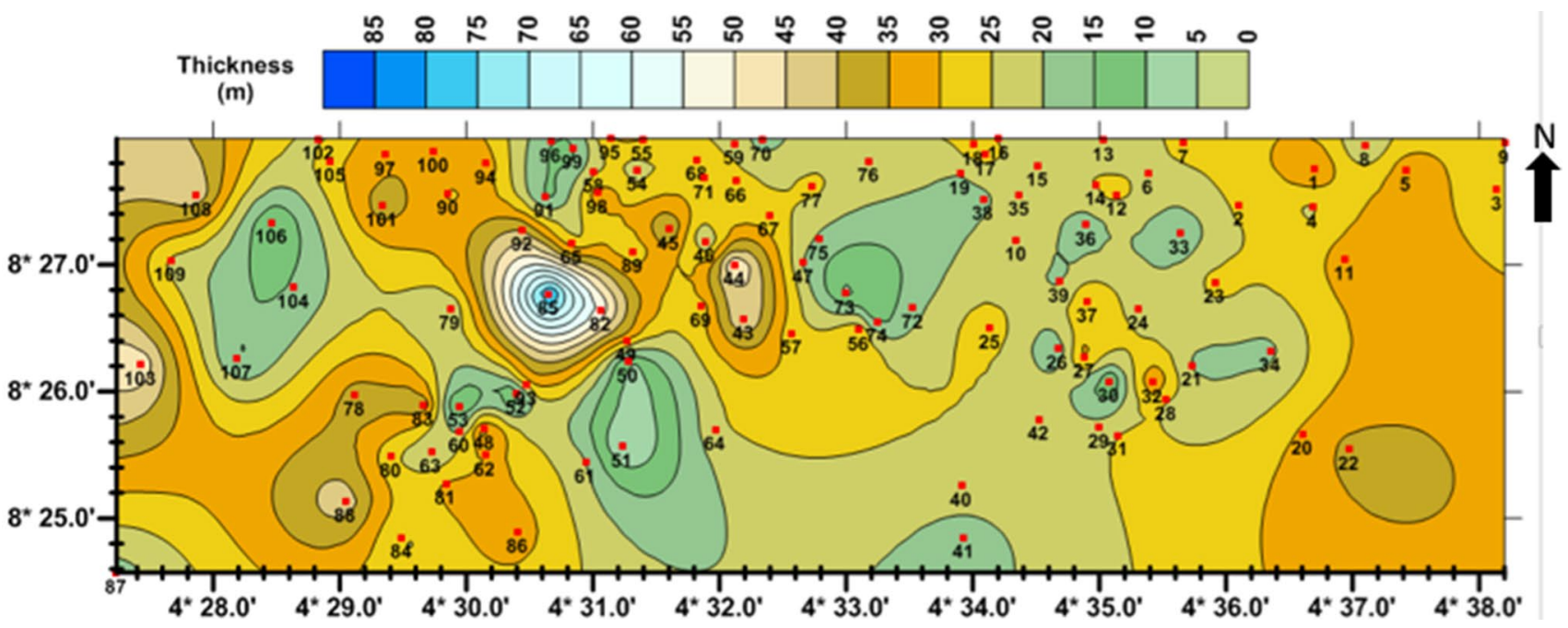

Fig. 5 Estimated total aquifer thickness

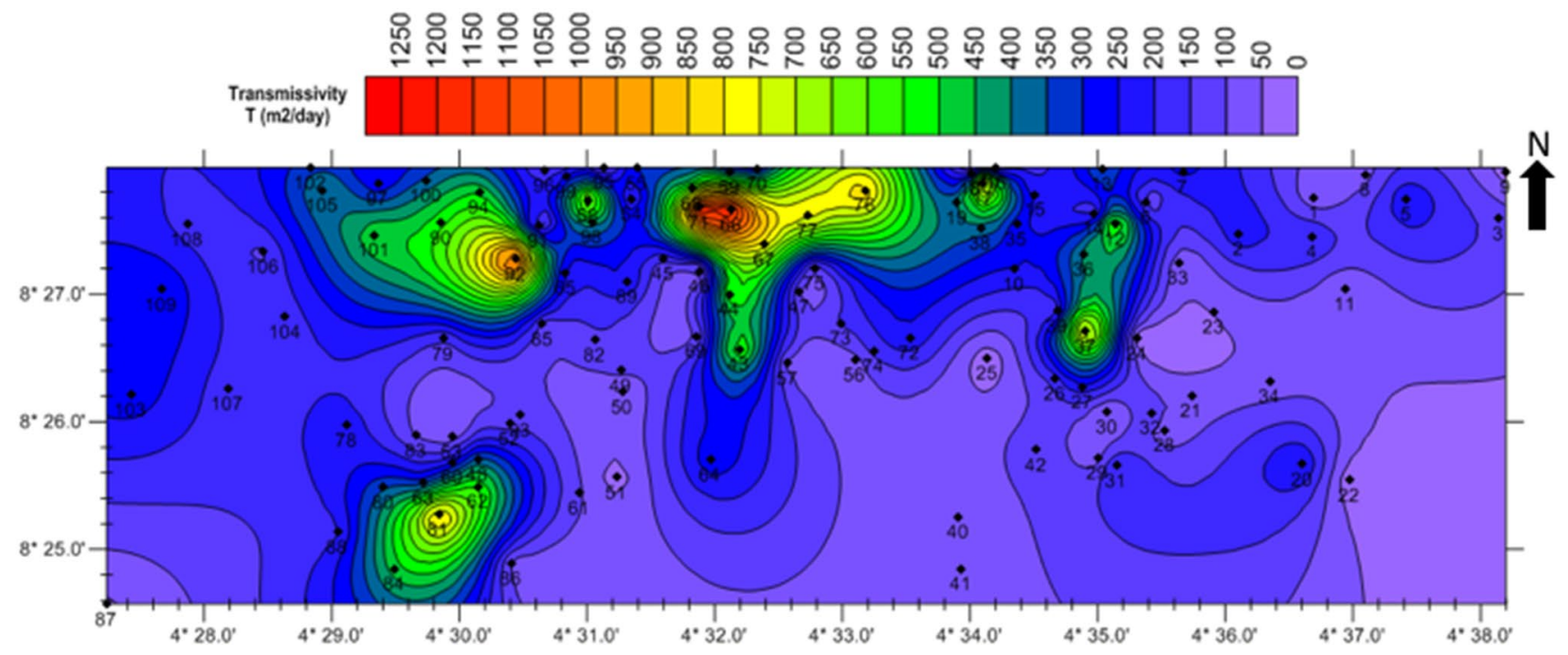

Fig. 6 Transmissivity of the aquifer in the study area

area. The values are generally moderate, ranging from 1 to $48 \mathrm{~m} /$ day with the highest values concentrated in the northcentral and southwestern parts of the study area. Hydraulic conductivity is an indicative parameter for aquifer recharge potential. It describes the vertical movement of water in the aquifer and can be used to express aquifers potential recharge where borehole pump data are unavailable (Heigold et al. 1979; George et al. 2015). Comparing Figs. 6 and 7, the spatial distribution of hydraulic conductivity is similar to that of transmissivity. A joint evaluation of the two parameters suggests that the aquifers in the north-central and southwestern parts of the study area have the highest potentials for groundwater in terms of borehole yield and aquifer recharge potential.
Refection coefficient $\left(R_{\mathrm{C}}\right)$ and fracture contrast $\left(F_{\mathrm{C}}\right)$ in weathered aquifers in contrast to the fracture aquifer are plotted in Figs. 8 and 9, respectively. Reflection coefficient and fracture contrast are indicators of water-filled fractures (Olayinka et al. 2000; Obiora et al. 2016). Comparing the fractured layer $(n)$ and the weathered layer $(n-1)$, low values indicate low contrast between the two aquifers, thereby suggesting good fractured network in the aquifers. Good fracture network implies high groundwater accumulation and fluid flow in the aquifers. As shown in Figs. 8 and 9, $R_{\mathrm{C}}$ ranges from -0.955 to 0.085 , while $F_{\mathrm{C}}$ ranges from 0.073 to 1.18 . The low values of reflection coefficient and fracture contrast are found in the western part of the study area. This suggest that the aquifers in the western part of the study area 


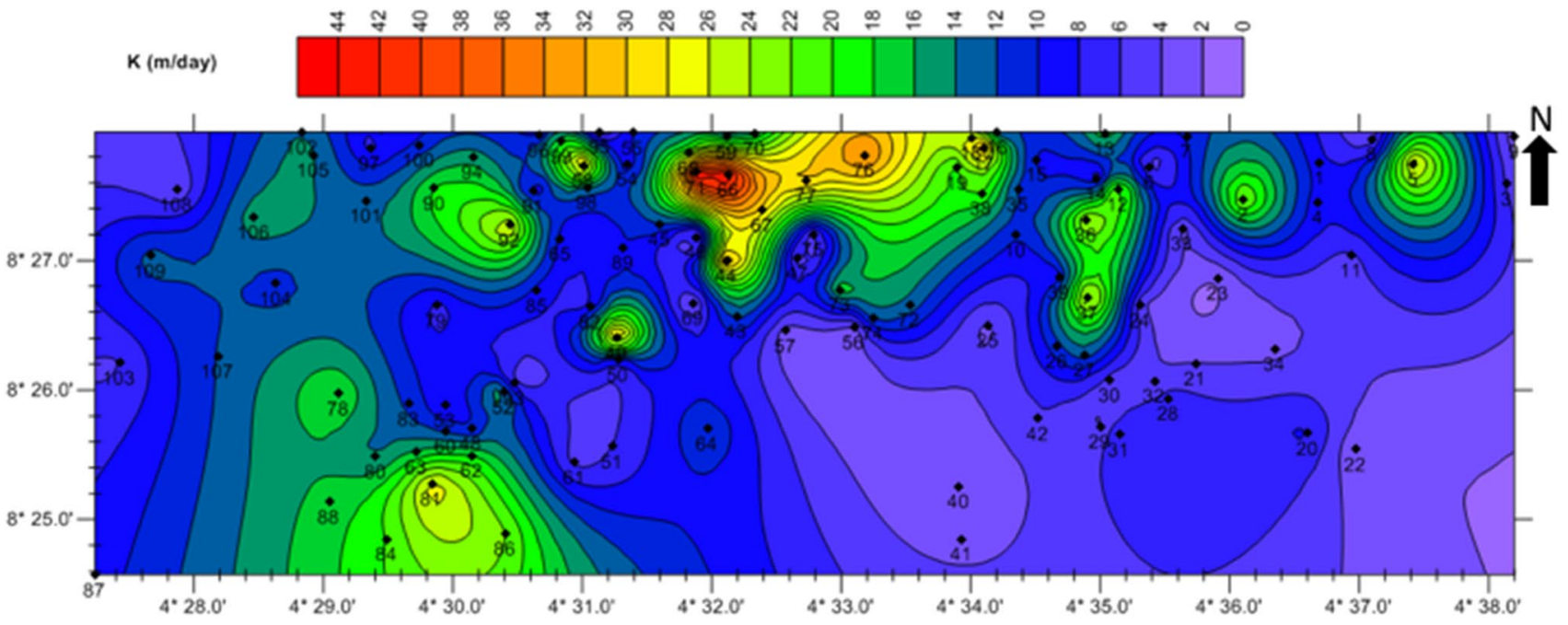

Fig. 7 Hydraulic conductivity of the aquifers in the study area

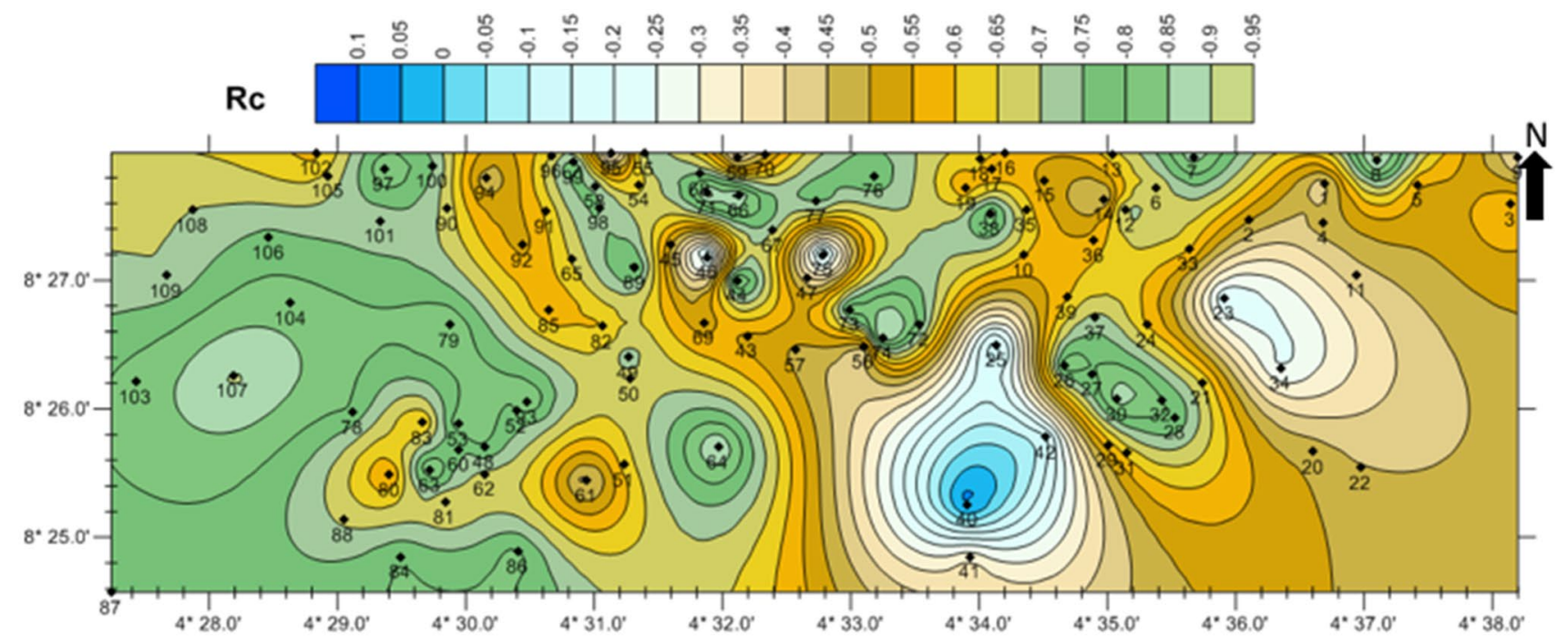

Fig. 8 Reflection coefficient map of the area

have higher density of water-filled fractures than the aquifer in the eastern part.

Finally, the joint parameters map here known as the indicative groundwater potential map is shown in Fig. 10. The map is a model of the overall groundwater potential comprising the direct and indirect groundwater parameters (aquifer thickness, transmissivity, hydraulic conductivity, and fracture contrast, reflection coefficient, and porosity) as defined in Eq. 3. The values of the indicative groundwater potential ranges from 0 to 1 . The areas with groundwater potential of 0.6 (i.e., $60 \%$ ) and above, on a scale of zero to one (0-1) are recommended for borehole drilling. Figure 10 also shows that the highest value of groundwater potential correspond to the extreme western, northwestern, and the central parts of the study area. In consideration of the groundwater potential of aquifers in the hard rock terrain (basement rock terrain), the size of the weathered aquifer and the availability of water-bearing fractures are the key indicators of high potential for groundwater. The larger the size of the aquifer adjudged from the thickness of the weather rock and the higher the fracture density, the higher the storage potential. From this study, the distribution of these two parameters (Fig. 5, 8, and 9) are spatially consistent with the overall groundwater potential map (Fig. 10). Therefore, it is reasonable to conclude that the extreme western, northwestern, and the central parts of the study area have the highest groundwater potential in the study area. It is recommended that boreholes should 


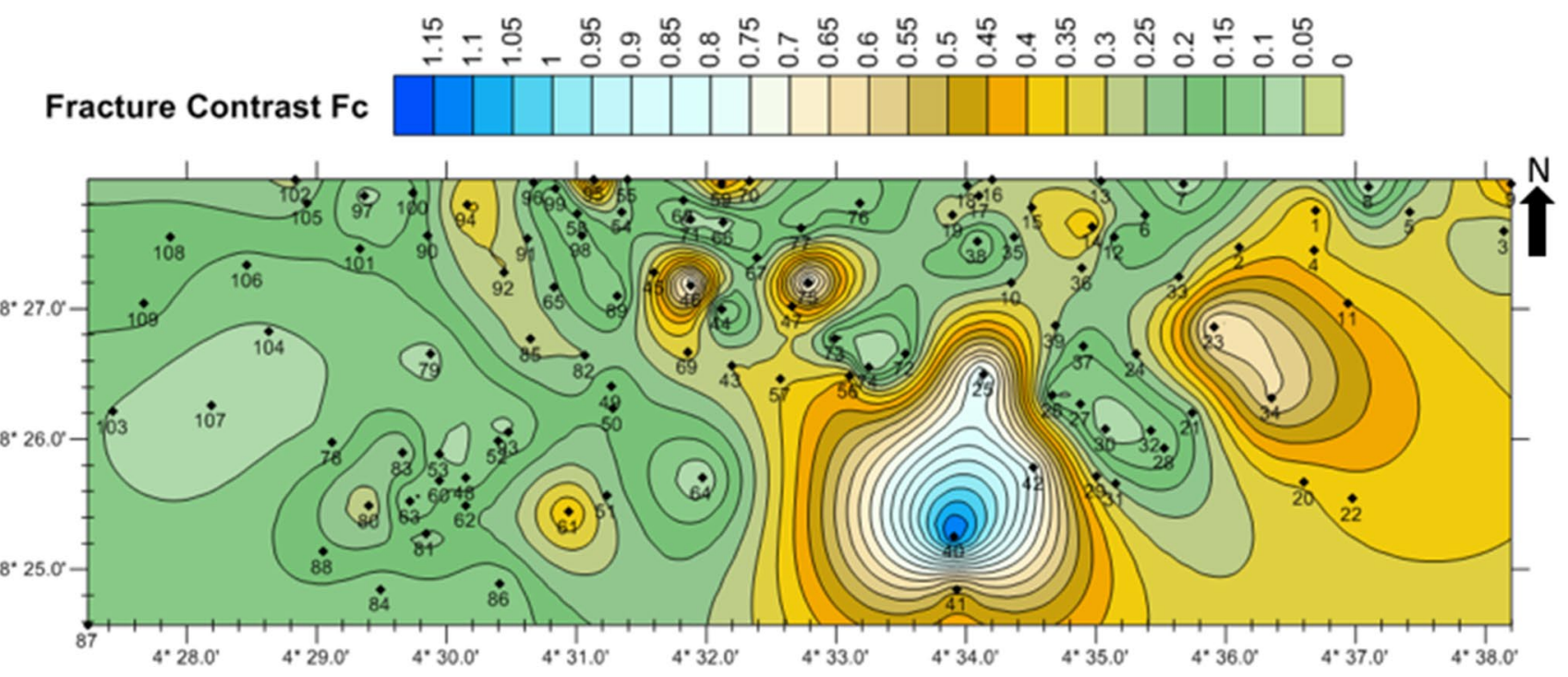

Fig. 9 Fracture contrast map of the area

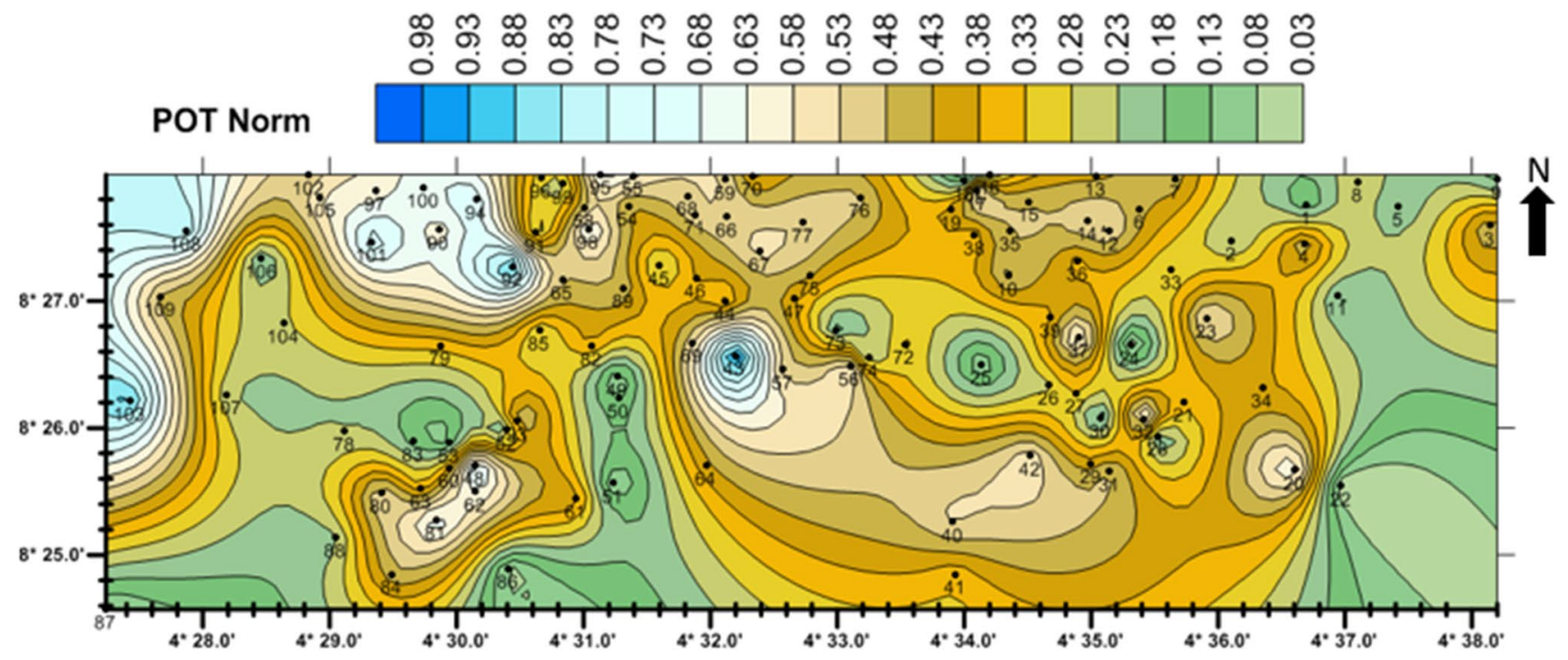

Fig. 10 Indicative groundwater potential map

be drilled in these areas to depth ranging between 75 and $100 \mathrm{~m}$.

\section{Conclusion}

Groundwater aquifer parameters and hydraulic properties of rocks estimated geo-resistivity data acquired in $110 \mathrm{VES}$ stations in an area measuring $161 \mathrm{~km}^{2}$ within geological sheet 223 Ilorin have been used to evaluate the groundwater potential of the bedrock aquifers in the area. Five geoelectric layer and two aquifer zones were delineated. The estimated thickness of the weathered and fractured aquifer ranges from 1.4 to $49.2 \mathrm{~m}$ and $0.6-33.6 \mathrm{~m}$, respectively, while the combined aquifer thickness ranges from 4.5 to $82.8 \mathrm{~m}$. The estimated hydraulic conductivity, transmissivity, and fracture density maps revealed wide variation in aquifer properties across the study area. The north-central and western parts of the study area were recommended for citing boreholes for community water supply. Although the groundwater potential model is subject to improvement for a more robust estimate, the consistencies between the overall groundwater potential map and the hydraulic properties of the aquifer confirmed the appropriateness of the model, developed in this study, for estimating groundwater potential of bedrock aquifers. 
Acknowledgements The authors gratefully acknowledge the anonymous reviewers for helpful suggestions. The triple E Research group members who participated in the data acquisition and processing are thankfully acknowledged.

Funding This study did not receive funding from any organization. Cost of study was funded by the authors.

Availability of data and materials Further study on the study area and the data is on going. The data can not be released to the public until the study is completed. The data can be released to the reviewers for verification purpose.

\section{Compliance with ethical standards}

Conflict of interest To the best of authors' knowledge, there is no known conflict of interest in this study and the information provided.

Code availability Not applicable.

Open Access This article is licensed under a Creative Commons Attribution 4.0 International License, which permits use, sharing, adaptation, distribution and reproduction in any medium or format, as long as you give appropriate credit to the original author(s) and the source, provide a link to the Creative Commons licence, and indicate if changes were made. The images or other third party material in this article are included in the article's Creative Commons licence, unless indicated otherwise in a credit line to the material. If material is not included in the article's Creative Commons licence and your intended use is not permitted by statutory regulation or exceeds the permitted use, you will need to obtain permission directly from the copyright holder. To view a copy of this licence, visit http://creativecommons.org/licenses/by/4.0/.

\section{References}

Abubakar YI, Auwal LY (2012) Geoelectrical investigation of groundwater potential of Dawakin Tofa Local Government Area of Kano State, Nigeria. Am Int J Contemp Res 2(9):1-10

Abubakar YI, Danbatta AU (2012) Application of resistivity rounding in environmental studies: a case study of Kazai crude oil spillage, Niger State, Nigeria. J Environ Earth Sci 2(4):13-21

Abubakar HO, Raji WO, Bayode S (2014) Direct current resistivity and very low frequency electromagnetic studies for groundwater development in a basement complex area of Nigeria. Sci Focus 19(1):1-10

Acheampong SY, Hess JW (1998) Hydrogeologic and hydrochemical framework of the shallow groundwater system in the southern Voltaian sedimentary basin. Hydrogeol J 6:527-537

Aluko KO, Raji WO, Ayolabi EA (2017) Application of 2-D resistivity survey to groundwater aquifer delineation in a sedimentary terrain: a case study of south- western Nigeria. Water Util J 17:71-79

Annor AE, Olasehinde PI, Pal PC (1987) Basement fracture pattern in the control of river channels. An example from central Nigeria. J Min Geol 26(1):5-11

Asry Z, Samsudin AR, Yaacob WZ, Yaakub J (2012) Geoelectrical Resistivity Imaging and Refraction Seismic Investigations at $\mathrm{Sg}$. Udang, Melaka. Am J Eng Appl Sci 5(1):93-97

Bhattacharya PK, Patra HP (1968) Direct current geoelectric sounding: principles and interpretation. Elsevier Science Publishing Co., Inc., Amsterdam
Casas A, Himi M, Tapias JC (2005) Sensibility analysis of electrical imaging method for mapping aquifer vulnerability to pollutants. In: Near Surface Geophysics Conference, Palermo

Dan-Hassan MA (2001) Determination of geo-electric sequences and aquifer units in part of the basement complex of north-central Nigeria. Water Resour J 12:45-49

Davis SN, DeWiest RJM (1966) Hyrogeology. Wiley, Hoboken

Edet AE, Teme SC, Okereke CS, Esu EO (1994) Lineament analysis for groundwater exploration in Precambrian Oban Massif and Obudu Plateau, S.E. Nigeria. J Min Geol 30(1):87-95

Ezeh CC (2011) Geoelectrical studies for estimating aquifer hydraulic properties in Enugu State, Nigeria. Int J Phys Sci 6(14):3319-3329

George NJ, Emah JB, Ekong UN (2015) Geohydrodynamic properties of hydrogeological units in parts of Niger Delta, southern Nigeria. J Afr Earth Sci 105:55-63

Graham MT, O’Dochartaigh BE, Ball DF, MacDonald AM (2009) Using transmissivity, specific capacity and borehole yield data to assess the productivity of Scottish aquifers. Q J Eng Geol Hydrol 42:227-235

Healy RW, Winter TC, LaBaugh JW, Franke OL (2007) Water budgets: foundations for effective water-resources and environmental management. USGS Report, Circular 1308

Heigold PC, Gilkeson RH, Cartwright K, Reed PC (1979) Aquifer transmissivity from surficial electrical methods. Ground Water 17(4):338-345

Kalinski RJ, Kelly WE, Bogardi I (1993) Combined use of geoelectric sounding and profiling to quantify aquifer protection properties. Ground Water 3(4):538-544

Koefoed O (1979) Geosounding principles I: resistivity sounding measurements. Elsevier, Amsterdam

Kosinski WK, Kelly E (1981) Geoelectrical sounding for predicting aquifer properties. Ground Water 18(2):163-171

Lott GK (1998) Thin section petrography of thirty-five samples from boreholes in the Cretaceous succession of the Benue Trough Nigeria. British Geological Survey Technical Report WH/98/174C (Keyworth: British Geological Survey)

MacDonald AM, Davies J, Peart RJ (2001) Geophysical methods for locating groundwater in low permeability sedimentary rocks: examples from southeast Nigeria. J Afr Earth Sci 32:115-131

MacDonald AM, Bonsor HC, Dochartaigh BEO, Taylor RG (2012) Quantitative map of groundwater resource in Africa. Environ Res Lett 7:024009

Niwas S, Singhal DC (1981) Estimation of aquifer transmissivity from Dar-Zarrouk parameters in porous media. J Hydrol 50:393-399

Obiora DN, Ibuoti JC, George NJ (2016) Evaluation of aquifer potential, geoelectric and hydraulic parameters in Ezza North, southeastern Nigeria, using geoelectric Sounding. Int J Environ Sci Technol 13:435-444. https://doi.org/10.1007/s13762-015-0886-y

Olasehinde PI, Raji WO (2007) Geophysical Studies on Fractures of Basement Rocks at University of Ilorin, South-western Nigeria: application to Groundwater Exploration. Water Resour 17:3-10

Olayinka AI (1996) Non uniqueness in the interpretation of bedrock resistivity from sounding curves and its hydrological implications. Water Resour J 7(1-2):55-60

Olayinka AI, Obere FO, David LM (2000) Estimation of longitudinal resistivity from Schlumberger sounding curves. J Min Geol 36(2):225-242

Olorunfemi MO, Fasuyi SA (1993) Aquifer types and the geo-electric/ hydrogeological characteristics of part of the central basement terrain of Nigeria (Niger Sate). J Afr Earth Sci 16(3):309-316

Oluyide PO, Nwajide CS, Oni AO (1998) The Geology of Ilorin Area with Explanations on the 1:250,000 Series, Sheet 50 (Ilorin). Geol Surv Nigeria Bull 42:1-84

Orellana E, Mooney H (1966) Master tables and curves for VES over layered structures. Interciencia, Madrid 
Oyawoye MO (1964) The geology of Nigerian basement complex-a survey of our present knowledge of them. J Nigerian Min Geol Metall Soc 1(2):87-102

Petford N (2003) Controls on primary porosity and permeability development in igneous rocks. In: Petford N, McCaffrey KJW (eds) Hydrocarbons in crystalline rocks, vol 214. Geological Society London, London, pp 93-107

Rahaman MA (1976) Review of the basement geology of southwestern Nigeria. In: Kogbe CA (ed) Geology of Nigeria, 2nd edn. Elizabethan Publication, Lagos, pp 41-58

Raji WO (2014) Review of electrical and gravity methods of near surface exploration for groundwater. Nigerian J Technol Dev 11(2):31-38

Raji WO, Abdulkadir KA (2020a) Geo-resistivity data set for groundwater aquifer exploration in the basement complex terrain of Nigeria, West Africa. Data Brief 31:1-8

Raji WO, Abdulkadri KA (2020b) Quantitative estimates of groundwater hydraulic parameters in non-sedimentary aquifers North CentralNigeria. J Afr Earth Sci 172:1-11

Raji WO, Adeoye TO (2017) Geophysical mapping of contaminant leachate around a reclaimed open dumpsite. J King Saud Univ Sci 29:348-359

Raji WO, Obadare GI, Odukoya MA, Johnson LM (2018) Electrical resistivity mapping of oil spills in a coastal environment of Lagos, Nigeria. Arab J Geosci 11:144. https://doi.org/10.1007/ s12517-018-3470-1

Raji WO, Abdulkadir KA, Rahman RA (2019) Evaluation of groundwater aquifers vulnerability in Ilorin Metropolis using electrical resistivity method of geophysics. Water Util J 23:27-36

Raji WO, Ibitoye PE, Abiri OA, Adepoju JA, Abdulkadir KA (2020) Comparison of six classical electrode arrays of $1 \mathrm{D}$ resistivity survey for subsurface delineation-field experiments. Centre Point J 26(1):79-97

Samaila NK, Singh GP (2010) Study of porosity loss due to compaction in the cretaceous upper Bima sandstone, upper Benue trough, NE Nigeria. Earth Sci India 3:105-114
Scanlon BR, Cook PG (2002) Theme issue on groundwater recharge. Hydrogeol J 10(1):3-4

Sharma SP, Baranwal VC (2005) Delineation of groundwater-bearing fracture zone in a hard rock area integrating very low frequency electromagnetic and resistivity data. J Appl Geophys 57:155-166

Shiklomanov IA (1998) Global renewable water resources. In: Zebedi $\mathrm{H}$ (ed) Water: a looming crises? Proceeding of the international Conference on World water Resources at the beginning of the 21st century. Unesco/IHP, Paris, pp 1-25

Telford WM, Geldart LP, Sheriff RE (1990) Applied geophysics. Cambridge University Press, New York. https://doi.org/10.1017/ CBO9781139167932

UNEP (2010) Africa Water Atlas. Division of Early Warning and Assessment (DEWA), United Nations Environment Programme, Nairobi

Vashisht AK, Aggarwal R (2016) Performance of cotton mat as pre-filtration unit for groundwater recharging. Curr Sci 111(10):1591-1595

Viase JM, Andrco B, Perles MJ, Carrasco F (2005) A comparative study of four schemes for groundwater vulnerability mapping in a diffuse flow carbonate aquifer under Mediterranean climate conditions. Environ Geol 47:586-595

Zohdy AAR, Eaton GP, Mabey DR (1974) Application of surface geophysics to groundwater investigations. United State Geophysical Survey, Washington

Publisher's Note Springer Nature remains neutral with regard to jurisdictional claims in published maps and institutional affiliations. 